\title{
Tasting Privilege and Privation during Asante Rule and the Atlantic Slave Trade
}

Waves of turbulence greeted Africans on the eve of the eighteenth century. What would later become first Britain's Gold Coast protectorate then its Gold Coast colony was subject to two major forces that were to have dramatic and sometimes devastating effects: the ramping up of the trans-Atlantic slave trade and the rise of the Asante state. While some areas were depopulated, others benefited from the increased wealth associated with Atlantic trade. Based in Kumasi, the Asante Empire was to rapidly expand into much of modern-day Ghana, creating opportunities for some and resulting in captivity for others. People privileged enough to control or fall outside of these turbulent tides witnessed fewer extremes, but were still affected by the changing fortunes of their neighbors.

Food was central to the experience of these events. Great food stresses for some enabled food excesses for others. From the eighteenth century onwards, pronounced inequalities developed across many West African societies involved in the slave trade, cleaving Africa's economic future on a different path from that of Europe (Green 2019). Yet inequality and its role has largely been overlooked in discussions of African food practices during this period. Instead, the dominant narrative has been a Malthusian one, where the adoption of American crops fueled population increases that led to the rise of complex polities like Asante (McCann 2005; Wilks 1977, 1993, 2004). These purported population increases are even hypothesized to have offset the losses suffered as a result of the Atlantic slave trade (Cherniwchan and Moreno-Cruz 2019; Crosby 2003; Curtin 1969). In this chapter, I critique these arguments and offer an alternative view that focuses on the varied food experiences of West Africans from the late eighteenth through the nineteenth century as a means to highlight inequalities in the food and political landscapes. 
This chapter's culinary odyssey begins in the Asante core, where the Asantehene (paramount chief) and his retinue displayed vast quantities of wild and domestic animals, tubers, and grains that boasted of their highly productive agricultural system and control over the countryside. For the remainder of the chapter, I use Banda's experience as a touchstone to explore the range of situations outside Asante's core. At various points in the eighteenth and nineteenth centuries, Banda's inhabitants tasted the full spectrum of privilege and privation through periods of relative stability as well as captivity, all reflected in and experienced through their foodways. In exploring this continuum, we can coax out the situated contexts in which scarcity emerged. The resulting cartography of food experiences compels us to think through diverse African agencies and inequalities as an antidote to homogeneous representations of a scarce Africa.

\section{AMERICAN CROPS AND WILKS'S BIG BANG THESIS}

In the early eighteenth century, central Ghana's political landscape was profoundly reshaped by the rise of the Akan-speaking Asante state and its subsequent expansion to much of modern-day Ghana (Arhin 1967a, 1967b; Wilks 1975). To Ivor Wilks, preeminent historian of Asante, food supply was critical to Asante's emergence. He posited that there was a "Big Bang" in the forest zone of Ghana in the fifteenth and sixteenth centuries, triggered by the development of agriculture and the acquisition of what he termed "unfree" labor. This new subsistence regime was fueled by the arrival of American crops and set in motion major transformations in relations of production as well as population increases (Wilks 1977, 1993, 2004). The Big Bang was financed by the development of the gold trade, which allowed forest dwellers the capital to secure unfree labor. Unfree laborers were especially critical in initial clearance of the forest due to the prohibitive labor costs of converting primary forests into agricultural fields (Wilks 1977).

While Wilks's argument has been the subject of numerous critiques (e.g., Chouin 2012; Klein 1994a, 1994b, 1996; Pavanello 2015; Shinnie 1996), the Big Bang thesis remains generally accepted among many Africanist historians (e.g., Chouin 2012, 17; Miller 2015-16) and beyond, even appearing in a recent New York Times article on African cuisine. ${ }^{1}$ In this section, I focus on the elements of Wilks's argument that specifically relate to African agriculture. The reasoning used to make these claims shows how contradictory evidence is often overlooked even by remarkable scholars, and how those evidentiary gaps are implicitly filled in with tenets of the scarcity slot. As we will see, Wilks's thought process was in part a product of the limits and affordances of the archives he relied upon, as well as of misconceptions that were-and to some extent remain_common among archaeologists and historians. I zero in on the Big Bang precisely because Wilks has clearly laid out his logic in multiple publications, for which he is to be commended. The Big Bang thesis is in many ways a highly conjectural outlier to Wilks's otherwise strong 
scholarship. This difference reveals the degree to which it is acceptable to speculate about the insufficiency of African agriculture where similar arguments about other skill sets (i.e., weaving, iron-making) would not be deemed credible.

Wilks's $(1993,2004)$ ideas regarding the origins of agriculture and settled life were rooted in a clever reading of Asante oral traditions and archaeological evidence. His central argument rested on the claim that there was no agriculture (Wilks 1993), or as he later modified it, no fully formed agrarian order (Wilks 2004) in the forest prior to the fifteenth or sixteenth century. He cites Asante origin myths that tell of hunters founding new sites for villages in the forest which were subsequently cleared so that farmlands could be established (Wilks 1977; 1993, 64-66). He tethers this myth to Oliver Davies's archaeological work near Kumasi, which located polished stone chisels that Davies argued were traded with early farming communities. Wilks concedes that this evidence suggests a degree of sedentary living and perhaps some cultigens in a subsistence regime reliant mostly on foraging. He is describing what archaeologists know as the Kintampo Complex, an early farming tradition in Ghana that dates to 3,000-3,500 years before present, long before it is possible to definitively trace the origin of Akan-speaking peoples. While Asante origin stories do accord hunters a central role in finding new villages, it is curious that Wilks interprets this as evidence of the existence of pre-agricultural hunter-gatherers. In Africa, hunters have long played central roles not only in hunting and gathering but also in agricultural societies (e.g., Dueppen and Gokee 2014; Gautier and van Neer 2005; Logan and Stahl 2017; Stahl 1999b; see also chapter 2), a role some still play today. Their range is wider than that of most villagers, since they can be gone for days or weeks in pursuit of animals, so it makes sense that they would act as scouts for new locations. Retracing Wilks's logic reveals the influence of the nineteenth-century writings of Thomas Bowdich, a young British merchant who visited Asanteland in 1817-18 and wrote extensively of his experiences, as well as perhaps the influence of the social evolutionary archaeological reasoning common at the time of Wilks's original exposition in the 1970s (Wilks 2004, 42-52). ${ }^{2}$ Curiously, he continued to insist upon this interpretation even after clear archaeological evidence became available indicating the existence of agriculture from 3,500 years ago to the present.

Recall that the period in question is the fifteenth and sixteenth centuries $\mathrm{AD}$, over two millennia after we have firm evidence for the development of food production and settled village life in central and northern Ghana (Casey 2000; Chouin 2012; D’Andrea and Casey 2002; Klein 1996; La Fleur 2012; Shinnie 1996, 201; Shinnie 2005; Watson 2010; Vivian 1992), including in Banda (Stahl 1985, 1986, 1999b, 2001). By 2004, Wilks was aware of some of this evidence, but nonetheless argued that agriculture did not cross the forest boundary for two millennia, despite evidence for large towns in Asanteland by $800 \mathrm{AD}$ (Vivian 1992, 161-62) that would have required an agricultural base. His reasoning relates to the high labor costs of converting primary forest into agricultural fields; the unsuitability of savanna 
crops to forest conditions; the relative unproductivity of yams; and the need for oil palms to be tended (Wilks 2004, 49-50). While I discuss the specific merits of some of these points in a moment, there is a larger issue at stake here: the assumption that Africans were incapable of significant environmental modification until very recently. He employed similar reasoning to argue, for example, that the spread of maize into the forest coincided with a drought that would have facilitated clearance (Wilks 2004, 65-66), rather than crediting sixteenth and seventeenth century farmers with the appropriate labor or skills to make this shift. ${ }^{3}$

Similar reasoning permeates many archaeologists' models of the earlier expansion of Bantu-speaking peoples from west-central Africa to southern Africa, about two thousand years ago. Active debates rage as to whether climatic-induced forest openings or anthropogenic clearance permitted the expansion of these agriculturally based peoples (compare Bostoen et al. 2015 with Garcin et al. 2018). Pearl millet is a savanna crop that is ill-suited to forest conditions, yet its consistent presence across archaeological sites in Central and West Africa suggests that farmers possessed the ability to modify their techniques to forest settings (Garcin et al. 2018). In central Ghana, the archaeological record is clear: people made intensive use of oil palm using arboricultural methods and used domesticated pearl millet and cowpea by 3,500 years ago (D'Andrea, Logan, and Watson 2006, 2007; Logan and D'Andrea 2012).

The idea that forest and savanna agricultural techniques were fundamentally incommensurate is also an exaggeration. Lying between forest and savanna is a thick band of transitional zone referred to as the forest savanna mosaic or the woodland savanna. Banda lies within the wetter part of this zone, and is characterized by high agricultural productivity in modern times, particularly of yams, sorghum, maize, and until recently, pearl millet. Although the quantity of rainfall received in Banda is less than in the forest, both areas share a two-peak equatorial rainfall pattern. The forest fallow system which is described by McCann (2005, 47-48) as unique to the forest relies on a nearly identical set of techniques and agricultural schedule to that employed by Banda farmers. These techniques were clearly highly developed in Banda by the fifteenth century (chapter 2) and probably by the beginning of the first millennium AD (Logan 2012) if not before (Stahl 1985).

Given this evidence, we must ask why the forest remains such a boogeyman to some Africanist archaeologists and historians. In Wilks's case, this idea may relate to early European sources that "misread the African landscape" (Fairhead and Leach 1996). For example, Wilks cites an anonymous Portuguese 1572 report in which the author was trying to deduce the locations of the gold mines in the forest, which local Africans did their best to obfuscate. Wilks $(2004,62)$ writes that the anonymous chronicler

knew something of the environment in the mining districts, "The land," he wrote, "does not enjoy the benefit of the sun on account of the great thickness of the trees, into which animals cannot penetrate, let alone the blacks." But obviously there were 
miners ... The implication of the 1572 Report is that at such sites hunter-gatherers were both prospecting and carrying out mining operations. The writer saw that the spread of agriculture was essential to the development of the extractive industry. "Once the hills have become opened, and the land cultivated," he predicted, "thereafter what is produced will be enormously increased ..."

Here Wilks is critical of the chronicler's remarks about mining, but appears to have accepted his contention that the land was uncultivated. Wilks was clearly aware of the pioneering research of James Fairhead (he is cited in Wilks's acknowledgments), who along with Melissa Leach demonstrated the multiple ways in which colonial officers misread African agricultural practice (chapter 2). Might a Portuguese chronicler with even less information also have misread-or even completely missed-forest-based agriculture? Tropical agricultural systems mimic the forest canopy to best make use of sun, water, and soil; multiple crops including tubers, grains, beans, and vegetables are all interplanted in the same fields. To European observers used to seeing clearly demarcated, monocropped fields, African agricultural plots must have looked chaotic and unrecognizable as proper agriculture or even as agriculture at all. The invisibility of these fields to the 1572 chronicler is evident in his observation of plantains growing in the forest, "where no one could have planted it" (Wilks 2004, 68). According to Dickson $(1964,25)$, another major source for this period, Dupuis (1824), seems to have misread the forest landscape in a similar fashion.

Wilks's Big Bang hypothesis was infused with new life by McCann (2005, 44), who argues that maize fueled the rise of agriculture in Asante. Rather than providing evidence for early uptake of maize in the forest, which to my knowledge is not recorded in any documentary or archaeological sources, McCann (2001, 258) points to the apparent synchrony of maize's introduction around 1500, the same time that Wilks proposed for the Big Bang. Yet we must be cautious in interpreting this coincidence, which is also when written sources first become available for the Gold Coast. With a degree of circularity, Wilks (2004) marshaled support for the association of maize with the Big Bang by suggesting maize may have spurred the development of agriculture in the forest. In this he appears to rely on Bowdich's (1819 [1873], 181-82) admittedly preliminary interpretation of twelve Asante lineage names: "Regarding these families as primæval institutions, I leave the subject to the conjectures of others, merely submitting that the four patriarchal families, the buffalo, bush cat, the panther, and the dog, appear to record the first race of men living on hunting .... The introduction of planting and agriculture seems marked in the age of their immediate descendants, the corn stalk and plantain branches." Key to Wilks's argument are this evolutionary interpretation by which hunting must precede agriculture, as well as his conclusion that the Akan "abrootoo" or corn (grain) stalk is equivalent to the more specific "aburoo" or maize. Bowdich, a merchant rather than a botanist or linguist, did not distinguish the specific plant to which he refers, using the British term "corn" to refer to grain 
in general. Bostoen (2007) notes a similar interplay of words for grain crops in many African languages. Words for the indigenous staples pearl millet, sorghum, and finger millet are often used interchangeably with each other and for maize as well. The limitation of this linguistic specificity make linguistically tracing maize difficult in areas that already have strong grain crop traditions, and highlight the need for archaeological data to investigate the roles of various grain crops.

McCann $(2001,2005)$ suggests that maize was needed to support diets in the forest that were protein-rich but carbohydrate-poor (an assumption Wilks [2004, 49] also makes, contra McCaskie [1995, 29]). McCann reasoned that pearl millet and sorghum could not have been successful in the forest due to their need for sunlight and a long dry season (McCann 2001, 257), though the evidence cited above substantiates the cultivation of pearl millet in the forest millennia ago. Yet maize also requires sunlight and hence forest clearance. Supporters of the maize hypothesis never address why people would have gone through the trouble to clear forest land for maize but not for the indigenous grains sorghum and pearl millet, which had much longer histories and for which there was a much stronger preference in the sixteenth and seventeenth centuries (chapter 2). Forest soils are also more fertile than savanna ones, even if sunlight is more readily available in the savanna (Richards 1985, 49). Although yams are well suited to growing in forest conditions, McCann (2001) argues they were merely prestige foods given their long maturity and high labor requirements. Wilks $(2004,49)$ also dismissed the potential contribution of yams to forest diets. Both scholars seem to have overlooked Miracle's (1966) comparisons of the productivity of maize versus other staples. In humid, forested areas, yams produce more yield per hectare than maize when considered in terms of calories, while in the park-like forest belts, yams, millet, and sorghum produce higher yields than maize (Miracle 1966, 206). In terms of calories per unit labor, the comparison is more equivocal, with maize performing only slightly better than yams (Miracle 1966, 210). Given the symbolic and ritual importance of yams to Asante, I suspect this slight advantage was insignificant.

Context- and ecozone-specific details like these are understandably sacrificed in the writing of general histories in order to make larger arguments, so the omission of such details in McCann's Maize and Grace is not surprising. In a laudable effort to demonstrate the relevance of African food history to global food history, McCann advances arguments that stem from a more general body of theory on maize's adoption in other parts of the world, particularly work by McNeil that credited maize with increasing populations and sociopolitical complexity (McCann 2005, 40-41). Archaeologists also commonly use this line of reasoning, for example to explain the introduction and spread of maize in eastern North America. McCann (46) draws inspiration from Wilks's Big Bang thesis, arguing that maize "spurred an agricultural carbohydrate revolution that allowed forest peoples ... to feed a dense growing population and fostered an elite political class, royal courts, and a standing army." Variations of this explanation for maize adoption are very common among Africanist archaeologists as well. 
There are logical flaws in the idea that maize spurred a carbohydrate revolution and in turn the rise of Asante. Miracle's arguments suggest that maize did not offer many, if any, advantages in terms of yield. Even if it did, McCann's explanation is ultimately rooted in the Malthusian logic that there is a straightforward calculation between calories produced and mouths fed, an equation that is often discredited once more archaeological data become available and when inequality is considered. Even today, people rarely choose the most optimal or efficient source of calories and instead gravitate towards culturally preferred foods. ${ }^{4}$ Calories are also a poor measure of nutrition. And all of these issues are complicated by differential access to food supply_-something which was likely important in a context of increasing inequality from at least the eighteenth century onwards (Green 2019). Each of these points is of major relevance in today's food security landscape, and thus it is critical we pay them heed when discussing the past. In order to do so, I attempt to evaluate the hypotheses that the forest was carbohydrate poor, and that maize made up for that lack, by evaluating extant data on Asante foodways. I also outline the food practices of Asante elite and commoners, which serve as a point of comparison for the remainder of the chapter, which focuses on food in Banda as well as among those captured as part of the Atlantic slave trade.

Like Wilks and McCann, I am constrained by an archive that largely focuses on nineteenth-century Asante (McCaskie 1995, 26), long after this so-called revolution would have taken place. With a few exceptions (e.g. Vivian 1992), there has been very little archaeology done on early Asante. I attempt to address this limitation in two ways. First, I review available information on Asante foodways, which date to primarily the nineteenth century, reasoning that if maize was as important as Wilks and McCann suggest, it would still have had an important role at this time. I acknowledge the limitation in this kind of argument, however, since people often employ crops like maize under a specific set of circumstances, and return to more preferred foods after that situation is over. Second, I investigate food in Banda, which by the last quarter of the eighteenth century was part of the Asante Empire. This too is an imperfect comparison, since Banda lies within a different ecological zone and the time period is somewhat later. Recall, however, that chapter 2 revealed a fully functional agricultural system capable of maintaining dense populations, even during drought, spanning precisely the centuries that Wilks credits with early, incipient agriculture in the forest. Although in a different ecological zone, the material record demonstrates dense trade relations with the forest and the northern savannas. Nearby Begho likely engaged in these connections with an even greater intensity. Given these relationships, as well as the similarities between forest and forest-savanna agriculture, it is difficult to justify Wilks's argument that there was an impermeable social and economic border between these two ecological zones.

In addition to evaluating the Big Bang thesis, my aim in this chapter is reframe the narrative by contextualizing human experiences of the eighteenth and nineteenth centuries through foodways. I see this as a necessary corrective to a 
history that has been dominated by Malthusian assumptions based on crop properties rather than by information regarding people's choices and tastes. Moving from the Asante heartland to its Banda outskirts to the Atlantic coast, what becomes painfully evident is the existence of a variegated food landscape that enabled some to enjoy great culinary excesses built on the extreme deprivation of others.

\section{THE ASANTE STATE}

The Asante are perhaps one of the best-studied polities in Africa, aided by a density of nineteenth-century visitor accounts, oral histories, colonial records, and the pioneering anthropological work of R.S. Rattray (1923) in the early colonial period. Political order and trade, particularly from the vantage of Asante elites (McCaskie 1995), were the focus of many of these archives and as a consequence, such topics defined historical scholarship throughout much of the 1960s-1980s (e.g., Arhin 1967a, 1967b, 1970, 1990; Wilks 1975, 1993). Asante history has since been broadened to include women, peasants, and social life (e.g., Allman and Tashjian 200o; Arhin 1983; Clark 1994; McCaskie 1995), among other topics common in social history. Yet for all the possibilities in this dense archive, we still know remarkably little about food and agriculture. For the present study, one of the values of elitecentric histories is that they provide us with a lens into the consumptive practice of people with high levels of access to preferred foods, and thus serve as an important point of comparison to the food experiences of the less privileged. In this section, I provide some basic context for discussion of Asante foodways, since economic positionality relates closely to one's food choices. Asante's expansion and reorientation of trade networks fundamentally changed the contours of inequality in the eighteenth century onwards, ultimately sweeping up Banda and many other polities into its imperial grasp.

The Asante state was and is based in Kumasi, a city situated to the north of Lake Bosumtwi in the forest zone. In the early nineteenth century, Kumasi itself was quite large, with population ranging between 20,000 and 25,000 inhabitants, many of whom were engaged in government business (McCaskie 1995, 33). Many government officials also owned farms that provided sustenance to the urban center and provided a major source of wealth. Those who labored on these farms were generally slaves, wives, children, and pawns (people who were given in service for a specific period as payment for a debt) (Arhin 1990, 527). Surrounding populations brought meat, agricultural products, and pito (local beer) to Kumasi markets to supply the urban populations. According to Bowdich ([1819] 1873, 320), market goods in Kumasi included local produce such as staples (yam, plantains, grains, sugar cane, and rice), vegetables (okra, peppers, and garden eggs), fruits (oranges, pawpaws, pineapples, bananas), meat (beef, mutton, wild hog, venison, monkey, smoked snails, and dried fish), and drinks (pito and palm wine). Imports from the north and Europe included household goods (mirrors, brassware, sandals, cloth, 
blankets, pillows, pipes, drinks, salt, tobacco, and calabashes), farm tools like hoe blades, crafting goods (thread and brass), and weaponry materials (iron, lead, flints, etc.).

Foods, crafts, and trade goods generated profits at thriving markets. Since Kumasi was within the tsetse fly belt, cattle and livestock from the north were important and expensive goods, with cattle costing up to six times more in Kumasi than in the northern trade center of Yendi (Bowdich [1819] 1873, 272). Beef, mutton, chicken, and horses were thus luxury goods that only the king and other high officials could regularly afford. Commoners purchased items like salt, cloth, iron, and craft products in markets. Specialist villages close to Kumasi produced craft goods like textiles, pottery, wood carvings, and objects in gold and other metals. Skills that were needed by a wider array of people, such as those of blacksmiths and potters, were distributed more widely throughout Asante. Yet others were closely monitored, particularly the production of state regalia (Arhin 1990, 527-28).

The primary medium of exchange for Asante elites was gold dust, rather than the cowries or metal disks that had been used in earlier periods, but these currencies continued to be used concurrently in the north (Arhin 1983, 473; Arhin 1990; Garrard 1980). Gold was central to the Asante state economy as both an export and for consumption in internal markets. From the sixteenth century onwards, gold trade out of Akan lands totaled over 3.6 million troy ounces (around 112,0oo kilograms) per century, not including the amount consumed within Ghana. Gold was also used for the production of paraphernalia for chiefs. Furthermore, the Asante maintained a substantial amount of gold in state coffers-as much as 800,000 troy ounces (around 25,000 kilograms) by the nineteenth century (Garrard 1980, 163-65). In the eighteenth century, the Asante turned from the export of gold to that of slaves, who were obtained through their expansionary military tactics and tribute demands (see below). After the 1807 British abolition of the slave trade, the gold trade resumed, as gold and ivory exports increased to Europe, and gold trade to the north continued (Garrard 1980, 157-58).

The Asante state was involved in trade on several scales (Arhin 1990; Boaten 1970). Interstate or foreign trade was the most important and lucrative. Asante traders supplied the northern polities of Dagomba, Gonja, and Gyaman (map 3) with forest-produced kola nuts and European goods, and in exchange obtained slaves, livestock, salt, iron bars, shea butter, and coarse cloths (Arhin 1990, 528; Boaten 1970, 35). Trade with Europeans required gold, ivory, slaves, and, later on, rubber, in exchange for firearms, lead bars, gunpowder, cloths, alcohol, and salt (Arhin 1990, 528). From the early nineteenth century, the Asante established a virtual monopoly on northern-focused trade through strict control over the distribution of firearms as well as the establishment of customs houses or checkpoints along trade routes, which charged taxes and tolls (Boaten 1970, 37, 40). Commoners were involved in the kola and later the rubber trade, but gold, ivory, and slaves were domain of the Asante state itself. Arhin (1990, 528-29) suggests that more 
wealth was generated from the northern rather than Atlantic trade since more people were engaged in it and it was based on kola nut. Kola nuts were an ideal trade commodity, since they grew wild near Kumasi and were available to all who were physically able to collect them, yet they were in great demand by Muslims to the north and east (Handloff 1987).

Even though northern-focused trade may have been more important to the average Asante citizen (Arhin 1987, 1990), the trade in gold and human captives to Europeans on the coast was critical to state finance as well as state expansion, particularly as a means to acquire firearms. The Asante court maintained trade relations with multiple European nations who had set up shop on the coast, which sometimes resulted in rivalries among these foreign powers. As hinted above, most of these interactions were marked with the two-way exchange of food and drink (McLeod 1987, 186). The importance of the northern and coastal trade is commemorated in much paraphernalia for chiefs, including foreign metal vessels, umbrellas, weight systems, staffs, and firearms, among other things (McLeod 1987, 184).

Asante expansion began before 1700 and Asante state influence reached its maximum extent by the early nineteenth century, when it included most of modern-day Ghana and southeastern Côte d'Ivoire (map 4; Arhin 1967a; Wilks 1975). Expansion campaigns in the eighteenth century were directed primarily northward, whereas in the early nineteenth century the focus was southwards. In eighteenth-century Asante, succession disputes and expansionary military campaigns dominated the royal agenda (Arhin 1967a). Asante expansion northwards began with the conquest of Wenchi in 1711-12 and Bono/Takyiman in 1722-23 (map 3). Begho may have also been invaded at this time, or might have gradually declined in prosperity and succumbed to internal struggles (Wilks 2005, 18) or dispersed to new markets (Stahl 2001, 149-50). Asante armies turned northwards and invaded Gonja and Dagomba in 1744 (Arhin 1967a, 74).

The spatial organization of Greater Asante included the metropolitan area of the political capital, the inner provinces, and the outer provinces (map 4). The boundaries of each were marked by control posts along major routes (one such post was in Banda, marking the boundary between inner and outer Asante: Wilks 1975, 54). Inner provinces were more tightly integrated with Asante, while control over outer provinces was more akin to indirect rule (Wilks 1975, 62). Inner provinces were considered subject provinces, which had "Asante law and Asante rights" (Christaller in Wilks 1975, 63), and most were Akan or closely related culturally (Arhin 1967b, 76). Subject provinces may have been forced to pay the same taxes as those in the metropolitan region (i.e., death taxes, war taxes, and household taxes), often in gold dust. Inner provinces were at a disadvantage, however, in that they could not raise revenue by raiding areas outside Greater Asante. Instead, they raided other polities in the inner provinces when additional revenues were needed (Wilks 1975, 69-70). Tributaries or outer provinces such as Gonja and Dagomba (map 3) maintained an even looser relationship with the 


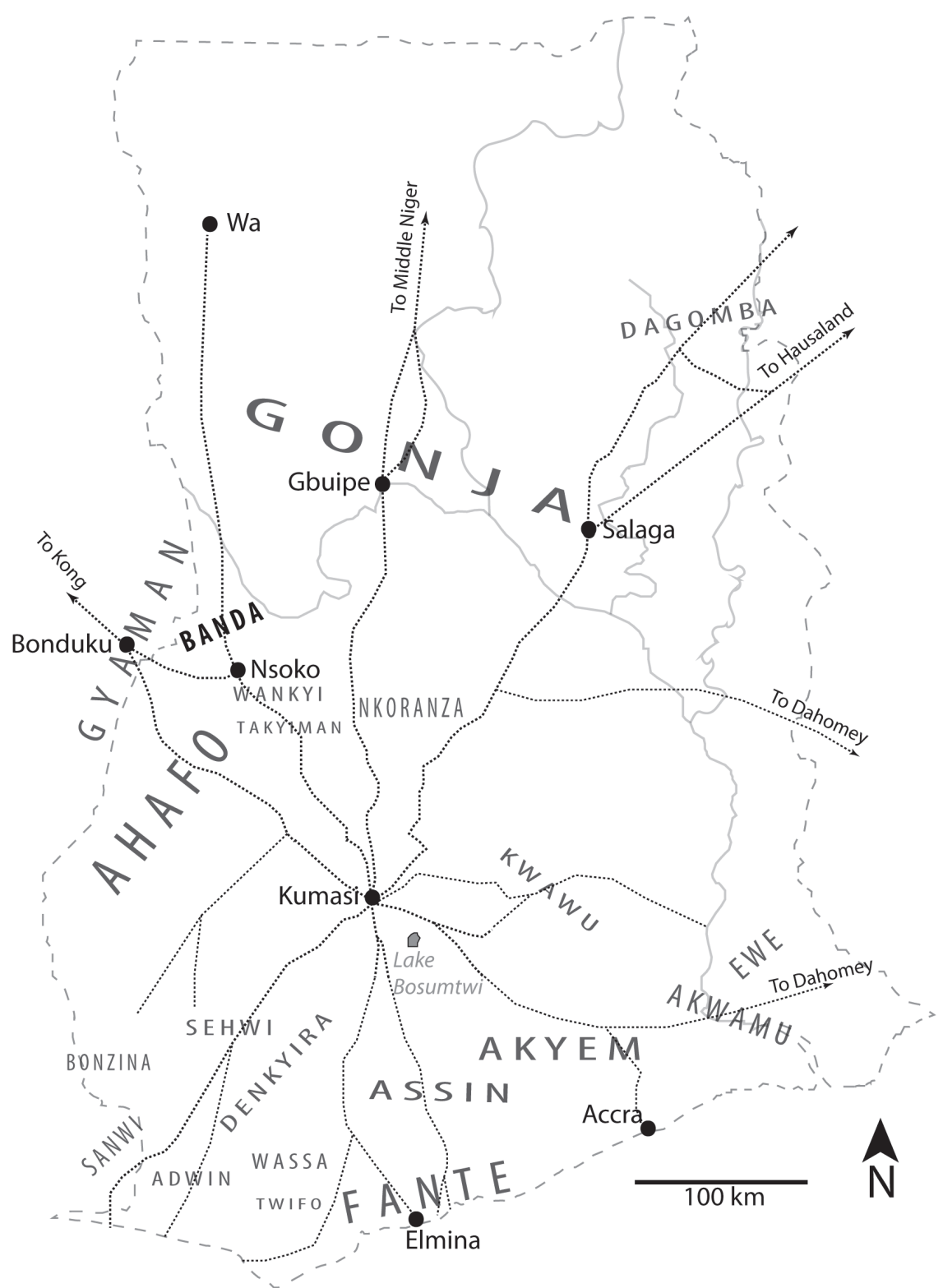

MAP 3. Nineteenth-century polities and Asante roads (after McCaskie 1995, 32, 76, 148). Solid lines are rivers, small dotted lines are roads, and larger dotted lines denote modern-day borders of Ghana.

Asante state. These communities were expected to make a financial contribution in goods or manpower, but their ties with the state were mostly commercial and often of mutual benefit. Asante demanded regular payments from tributaries, but 


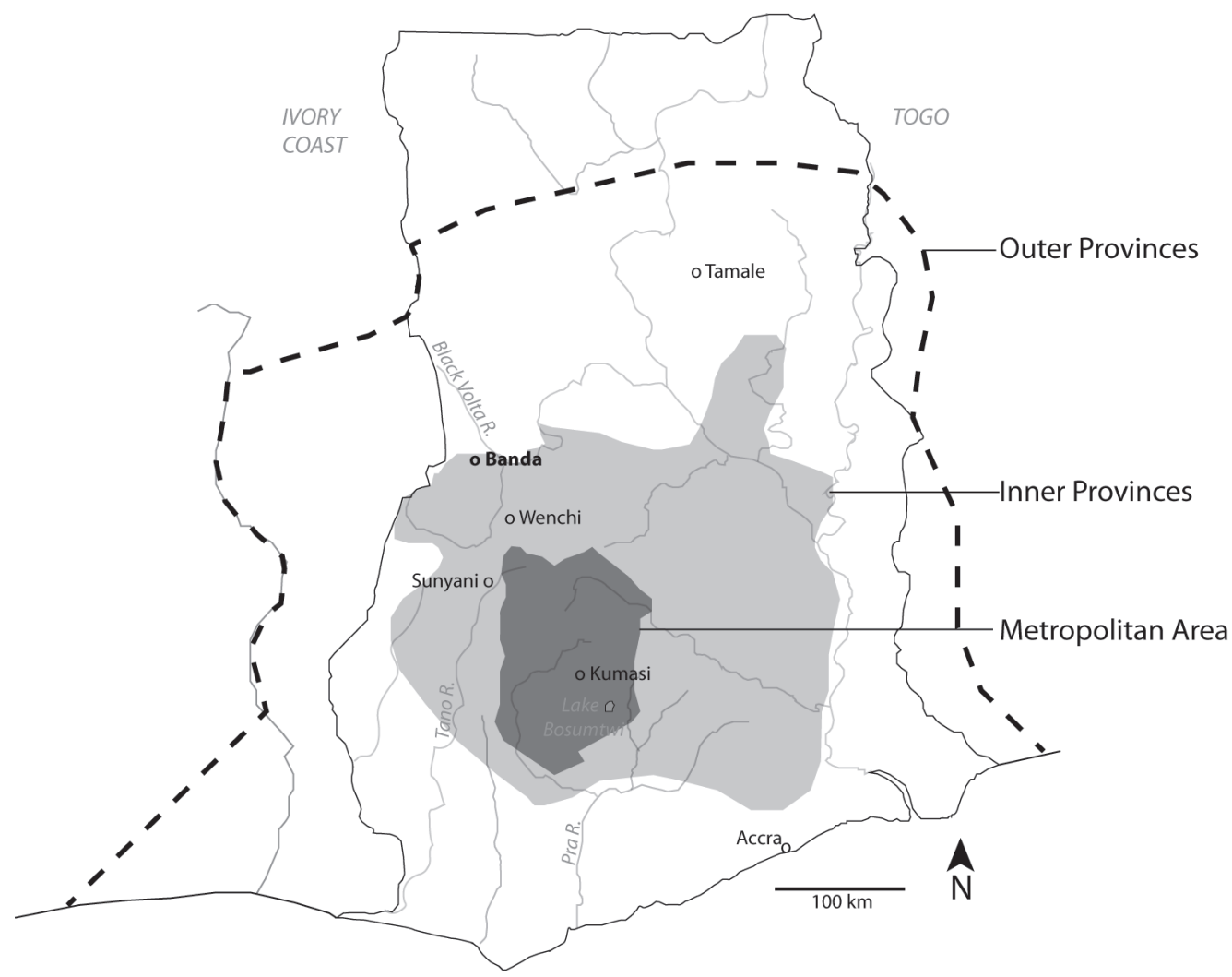

MAP 4. Geopolitical divisions in Asante in the early nineteenth century (after Wilks 1975, 62).

tributaries maintained political independence from Asante. Outer provinces were not required to participate in military ventures with the Asante (Arhin $1967 \mathrm{~b}$, 76-77).

The Asante government demanded two kinds of tribute after its conquest of an area. The first was a payment made soon after defeat that was intended to defray the costs of the Asante expedition. The second was an annual tribute requirement. Payment to the state was in money (gold dust, cowries, etc.) or in kind (in slaves or products of the new territory). Payment in products was the norm in areas that relied on cowrie-based rather than gold-based currencies, which included most of northern Ghana (Arhin 1967a, 286-87). Dagomba, for example, paid "500 slaves, 200 cows, 400 sheep, 400 cotton cloths, and 200 cotton and silk cloths," and Takyiman a smaller proportion of the same kind (Bowdich 1873, 269). Yet other communities, such as the Europeans on the coast, paid by means of "notes" or a ground rent of sorts that focused more on providing subsistence, that is, food monies (Arhin 1967a, 287). Tribute demands differed based on the size of the polity 
and the degree to which it was able to supply gold or other goods. These tributary relationships effectively transferred considerable surpluses from local polities to the centralized Asante state, concentrating wealth and power in Kumasi.

\section{TASTING AFFLUENCE IN THE ASANTE CORE}

Food was one of the central ways in which power and status was experienced and displayed in nineteenth-century Asanteland. European visitors frequently detailed the ingredients and presentations of elaborate feasts that no doubt communicated the wealth of the Asantehene and his retinue (Miller 2015-16). Despite these accounts, remarkably little has been written on the food history of the Asante. This is a larger project beyond the scope of this volume. In this section, I detail only a small portion of the available archive as is relevant to the Wilks/McCann hypothesis as well as to the understanding of elite consumption. First, I examine the role of maize relative to other introduced and indigenous carbohydrate sources. Second, I evaluate the relative abundance of food in the Asante heartland by exploring the diets of high- and low-status individuals. This examination of food status displays reveals that maize seems to have played a minor role in Asante cuisine, and that meat was highly valued.

The idea that maize was a mainstay of early Asante diet appears to have originated from two sources: its apparent role in Asante symbolism and its widespread adoption along the coast. The interpretation of maize's role in Asante origin myths has already been questioned in the previous section. Both Wilks and McCann cite an Akan proverb, "Aduane panin ne aburoo," which translates "the chief/ elder among foods is maize" (Christaller and Lange 200o). While the proverb is intriguing, no context or etymology is provided and it may well derive from the twentieth century, when maize did become important for a number of reasons (chapter 5). Without additional chronological details, historical linguists consider proverbs as notoriously difficult to date with any confidence (Stephens 2018b, 791), so their deployment as such in Wilks's account needs to be taken with a grain of salt. Historical documents from the coast are more numerous and attest to the rapid spread of maize around European forts (e.g., de Marees 1987). Carney and Rosomoff (2009) have interpreted the quick uptake of maize to its central role in provisioning European forts and ships, an observation I return to at the end of this chapter. What is less clear is the degree to which Africans themselves relied on the crop, particularly in the interior occupied by Asante and other groups (see La Fleur 2012, 150-53 for an intriguing suggestion regarding pellagra). ${ }^{5}$

Other scholars argue that maize played a more limited role in Asante. Both Dickson $(1964,27)$ and McCaskie $(1995,27)$ associate Asante's use of maize with its military campaigns, based on the observations of G.A. Robertson in 1818 that the cultivation of maize had been "lately more extensively introduced into the interior of Ashantee; both from its importance in feeding their stock, and being portable 
for the supply of their armies" (Robertson 1819, 201). To Dickson (1964, 27) the advantages of maize, a portable, storable surplus, were manifold over the main Asante staples of yam and plantain, which are cumbersome and subject to rapid spoilage. The indigenous grains sorghum and pearl millet, however, were not only more widespread in most conquered areas (Dickson 1964, 27), but have a considerably longer shelf life than maize. Bowdich's (1819 [1873], 250) description of soldiers' fare, for example, leaves considerable room for interpretation: “The army is prohibited during the active parts of a campaign from all food but meal, which each man carries in a small bag at his side and mixes in his hands with the first water he comes to; this, they allege, is to prevent cooking fires from betraying their position or anticipating a surprise. In the intervals (for this meal is seldom eaten more than once a day) they chew the boossee or gooroo [kola] nut. This meal is very nourishing and soon satisfies; we tried it on our march down."

Note that the crop used to make the meal is not specified; perhaps this is purposeful, since most grain crops can be ground and eaten in this fashion, providing troops with a considerable degree of flexibility. The preparation method described for soldiers-a ground flour mixed with a bit of water-was until recently a common preparation in Banda (Nafaanra: sisa) using pearl millet or maize and served to men upon their return from the fields. This technique may have been learned during Banda's service in Asante's army (below), and also raises the possibility that other crops were eaten in addition to maize. Even cassava can be made into a coarse meal, known today as gari. Asante's soldiers were probably dependent on the areas they invaded for at least part of their provisions, and would have presumably consumed whatever grain was commonly grown in these locations. Asante conquered areas from the dense tropical forest north to the drier savanna woodland, environments which would have posed different constraints on the crops being cultivated. The degree to which Asante soldiers relied on maize likely varied over time as well. Dickson cautions that the Asante may have learned of virtues of maize only in 1806 , with the beginning of campaigns to southern Ghana, where maize was grown more extensively. ${ }^{6}$ McCaskie $(1995,27)$ suggests that the popularity of maize waxed and waned with Asante's military campaigns, decreasing between 1800 and 1900 . What seems likely from this limited historical data is that maize was a strategic resource used to fill certain aims of Asante, rather than an important source of carbohydrates for the populace.

Even better suited to cultivation in Asante's immediate forest hinterlands was plantain, which La Fleur (2012) argues was the more revolutionary carbohydrate. Plantain was introduced possibly much earlier via the Indian Ocean and eastern Africa. La Fleur $(2012,108)$ argues that the increased focus on gold, with its attendant labor requirements, may have created a need for a high-yielding crop like plantain, particularly in the forested environments surrounding gold fields. Unfortunately, crops like plantains do not preserve well in the archaeological record, making it difficult to evaluate this thesis; analysis of phytoliths from archaeological sites could be marshaled in the future. However we must be attentive to these archival blind 
spots, because they significantly constrain our ability to re-create past foodways. Other root and tuber crops like yams and cassava are similarly obscured in the archaeological record, forcing us to rely on documentary and linguistic evidence.

Documentary evidence suggests that cassava arrived on the Gold Coast in the late seventeenth or early eighteenth century, though it was some time before Africans began planting it (La Fleur 2012, 156-57). Cassava was probably introduced into Asante Brong-Ahafo by 1806. Cassava has many advantages over yams, with which it was probably in competition in both fields and cooking pots. Cassava produces high yields in depauperate soils, requires little cultivation, and the tubers can be left in ground for a long time (Dickson 1964, 26-27, 1969, 119). Yams require prime land, are harvested only once a year, and require considerable investments in agricultural labor. Despite these differences in efficiency, La Fleur (2012) illustrates a strong preference for yams and marked dislike of cassava's taste. Cassava was considered poor man's food at least from the eighteenth to the early twentieth century along the coast, and may have been used to make up periodic shortfalls in more desirable crops (La Fleur 2012; McCaskie 1995, 27; see also Ohadike 1981 and chapter 4). In other words, cassava was used strategically when yams were not an option.

Besides the introduction of cassava, Dickson sees little change in what was actually cultivated between 1700 and 1800 on the coast, which according to both Bosman (1705) and early nineteenth-century writers included guinea corn (sorghum), pearl millet, maize, rice, and yams (Dickson 1964, 26). A smattering of other crops were introduced in the eighteenth and nineteenth centuries, including members of the onion family, breadfruit, cocoyams, tomatoes, and avocados (Alpern 1992, 2008). The New World cocoyam (Xanthosoma mafaffa), a more palatable cocoyam, had been introduced by the 1840 s, likely replacing the other cocoyam, Colocasia esculenta, which contains significant calcium oxalate, a digestive irritant (McCaskie 1995, 27). Around 1700, maize had established a niche on the coast but was still secondary to sorghum and pearl millet; by 1800 maize was perhaps more common, though sorghum still dominated in many areas and pearl millet was still grown. Rice was also produced in large quantities on the coast, along with yams, oil palms, coconuts, pineapples, sweet potatoes, bananas, sugar cane, et cetera (Dickson 1964, 26).

Nineteenth-century sources reveal that maize as well as cassava were not a significant part of Asante diet. This point is underscored in Bowdich's ([1819] 1873) observations of diet in Kumasi. He discriminates between white soups and black soups, the latter made with palm oil, though we learn little else of their ingredients. The starch commonly was yam or plantain, at times made into fufu (a firmtextured pounded food; chapter 5). Bowdich (267) notes that "they do not make cankey [kenkey] of their corn (a coarser sort of kouskous not cleared from the husk) as the Fantees do, but they roast it on the stalk, and when young the flavour closely resembles that of green peas." This statement implies that the Asante "corn" (i.e., grain) may have been pearl millet, which was eaten as a couscous, rather than maize, which was commonly consumed along the coast by their southern Fante neighbors as kenkey. ${ }^{7}$ It also suggests that maize was prepared by roasting 
on the stalk, rather than as a starchy staple. La Fleur $(2012,94)$ observes that the forest would have presented challenges to maize storage, since it was particularly susceptible to fungi and spoilage. These constraints meant that people probably favored floury types of maize that could be harvested fresh rather than dried and roasted as a snack or prepared as a vegetable accompaniment to main meal. In sum, the evidence from Asanteland itself suggests that maize was a minor food, painting a much different picture than what has been argued in the Wilks and McCann hypothesis.

If Asantes were not reliant on maize, what did they eat, and how did food vary across social class? Our most detailed archive derives from the accounts of European visitors to the Asante court in the nineteenth century. Quantity and quality of food and drink seem to have played central roles in Asante feasts and in Asante state encounters with European delegations. Upon his arrival, Thomas Bowdich $([1819] 1873,129)$ and his retinue were greeted by the Asantehene and conducted to a breakfast reception, "where a relish was served (sufficient for an army) of soups, stews, plantains, yams, rice \&c. (all excellently cooked), wine, spirits, oranges, and every fruit." Later that day, dinner was also provided, which apparently exceeded all expectations. Elements of the meal seem to have been prepared specifically for the European audience, including a heightened table as well as silver cutlery. A roasted pig was the central dish, as were

roasted ducks, fowls, stews, peas-pudding, \&c. \&c. On the ground on one side of the table were various soups, and every sort of vegetable and elevated parallel with the other side, were oranges, pines, and other fruits; sugar-candy, Port and Madeira wine, spirits and Dutch cordials, with glasses. Before we sat down the King met us, and said, that as we had come out to see him, we must receive the following present from his hands: two ounces four ackies of gold, one sheep and one large hog to the officers, ten ackies to the linguists, and five ackies to our servants. We never saw a dinner more handsomely served, and never ate a better. (130)

Bowdich's experience was one among many, as British delegations in particular sought to establish commercial ties with Asante in the wake of the 1807 abolition of the slave trade. Not all delegations were met with such pomp, as the Asantehene also communicated power through withholding offers of food or drink during hours-long receptions (Sheals 2011 in Miller 2015-16, 37).

Beyond state dinners, feasts also communicated abundance and power through consumption, as is revealed in Bowdich's (226-30) detailed account of the Yam Festival. While he omits what people actually ate, the dynamics he describes say much about hierarchy and consumption in Kumasi and beyond. Social norms appear to have been suspended for all in attendance; as Bowdich (226) reveals that normal punishments were suspended for infractions committed during the festival, where "the grossest liberty prevails." The Asantehene offered copious amounts of rum (an expensive, imported drink) in large brass pans (also imported) for the 
crowd to drink. Despite spilling more than they drank-another show of excesspeople quickly became very drunk. At the same time the brutality and life-anddeath power of the state was emphasized by constant musket fire and the display of the severed heads of chiefs who had revolted, as well as the sacrifice of a large number of slaves. Each of the chiefs present sacrificed several slaves, according to Bowdich (228), so "that their blood may flow into the hole from whence the new yam is taken." At the palace, the king also sacrificed twenty or so sheep, pouring their blood as well as palm oil and eggs on family stools and doorposts. After the ceremony was completed, the royal household ate new yam for the first time in the market, signaling that it was time for the populace to enjoy the tuber as well.

We must acknowledge that sources like Bowdich were written by occasional visitors who were shown only a very limited slice of Asante life, primarily that of the nobility and soldiers. We also do not know what festivals looked like when performed outside of the gaze of European visitors, and to what degree the great excesses observed by Bowdich were a performance meant to impress Asante's might upon him. McCaskie (1995, 34, based on interviews) offers us a glimpse of the lavish daily meals of the Asantehene, the paramount chief or king of Asante:

The Asantehene's household alone daily consumed large quantities of food . . . together with a leavening of imported delicacies. The Asantehene Kwaku Dua Panin (1834-1867) took breakfast about 8 a.m.; meat, plantain and yam "in large quantities" were distributed to the Asantehene's wives and children. The main meal of the day was taken at 2 p.m., when the Asantehene and his household officials made a selection from "mutton, turkeys, ducks, fowls, wild game of all kinds, except the buffalo; and fish from the lakes, and adjacent rivers ... also yams, plantains, beans, rice, European biscuits, tea, sugar, wines, liqueurs, etc." Immediately afterwards, "large dishes containing the great family dinner" were distributed, like breakfast, to the royal wives and children.

The main food of other elites was a "soup of dried fish, fowls, beef or mutton (according to the fetish), and ground nuts [peanuts] stewed in blood," while the poorer classes apparently made do with "soups of dried deer, monkey's flesh, and frequently of the pelts of skins" (Bowdich [1819] 1873, 267). Note here the emphasis in both accounts on animal/meat products rather than starch. Among the starches, in McCaskie's account, yams, which are of well-known ritual and subsistence importance, are mentioned first, followed by plantains, beans, and rice, but curiously there is no mention of maize, sorghum, or pearl millet. It is curious that both McCaskie's later informant and Bowdich (in two instances) highlight animal products before starchy ones, and identify these animals in much more detail than the botanical constituents of meals. It is unclear whether this listing reveals the importance of animal versus plant foods in such displays or is an artifact of European chroniclers' preferences. This practice might suggest that animal products were of higher value than starches to the court. A similar valuation appears to have 
been the case along the coast (La Fleur 2012, 134), in Dahomey (Monroe and Janzen 2014), and is suggested by the animals offered as gifts to Bowdich's entourage.

Food archaeologists have long argued that valued foods are often the ones that are the most rare or difficult to acquire, with common foods often assuming a lower status (Hastorf 2003). In Asanteland, available source material suggests that domestic livestock was in shorter supply than carbohydrates. Since much of the empire was below the tsetse fly belt, there was an increased risk of sleeping sickness, making livestock rearing riskier there than in drier locations like Banda and its northern neighbors. Consequently livestock and particularly cattle were highly valued for their meat and hides and were always in short supply in Kumasi (Arhin 1987, 57; Bowdich [1819] 1873, 272). This short supply may have impacted the ability of commoners to access domestic meat on a regular basis. However, there seems to have been ample wild game available in central Asante, ranging from elephants to river fish, and hunting was an established part of the Asante economy. Snails were a particularly important, if seasonal, source of protein (McCaskie 1995, 27-29).

The abundance of agricultural produce expressed in these accounts of the Asantehene's daily meals and his gifts to foreigners boasted of a flourishing agricultural system under state control (McCaskie 1995, 33-35). European observers of nineteenth-century Asante commented on the prevalence and intensity of its agriculture and the abundance of crops produced (Dupuis [1824] 1966; Hutton 1821, 203; Wilks 1993, 49). This was especially true around urban centers like Kumasi, while areas farther afield appear to have enjoyed longer fallows and less intensive agriculture (Wilks 1993, 50). Farther north, the density of farmed land increased as one approached major towns and satellite towns charged with producing crops for the urban areas (Dickson 1964, 27). The highly organized and intensive farming system surrounding Kumasi functioned essentially to supply the state apparatus; their surplus appears to have been large enough to support the Asantehene and his retinue, government officials and members of the elite class, as well as local markets (McCaskie 1995, 33-35). There were, however, real limits on transport of perishable foodstuffs, necessitating state-controlled agricultural intensification by the late nineteenth century through shortened fallows and concentrated labor inputs (McCaskie 1995, 36-37).

It is more difficult to evaluate food security in Asante, particularly among the non-elites, since very little of our historical evidence speaks directly to their food habits. McCaskie $(1995,29)$ reasons that "deficiency diseases recorded in the $19^{\text {th }}$ century tended to be related to protein shortages, or to failure to maintain a balanced diet, rather than absolute caloric sufficiency, malnourishment or starvation." He bases this finding on notes from a visiting British doctor, H. Tedlie, whose observations and treatments were recorded in a materia medica posthumously published in Bowdich ([1819] 1873, 282-92). While the doctor does mention that the poor and slaves suffered from parasitic and other cleanliness-related diseases, to the best I could tell none of the diseases he recorded are caused primarily 
by food, including protein, deficiencies. In fact, no European sources attest to severe food shortages in central Ghana until agricultural systems collapsed under the civil war that plagued Asante in the 1880s (McCaskie 1995, 29). Land also appears to have been plentiful compared to population (McCaskie 1995, 30), suggesting high availability of cultivated food products.

In sum, these historical records suggest that Asante's core enjoyed a relatively high degree of food security during the nineteenth century, supported by an extensive agricultural system, as well as hunted and traded animal protein. European observers were impressed by what they saw, and indeed, the resulting historical narratives are excellent sources of information on elite food practices. Yet they leave out people on the margins of society, like pawns and slaves, as well as people occupying the edges of the vast empire. In the next section, I consider how Asante rule impacted everyday life in Banda from the 1770 s to the 1820s, using archaeological remains, which speak to food practices at a much different scale than historical records. In the final section, I turn specifically to those who suffered the most: captives and pawns. Cumulatively these food experiences speak to an uneven culinary topography that overturns and complicates a simplified Malthusian view of African foodways.

\section{TASTING IMPERIAL CONTROL IN \\ BANDA, C. 1774-1820S}

In chapter 2, I paint a very different picture of agricultural capabilities in the fifteenth and sixteenth centuries than do Wilks and McCann. Banda had a fully formed agrarian order that was resilient enough to sustain even the most intense, prolonged drought on record in the last millennium. And its people did so by relying on pearl millet, a crop which has sustained African populations for millennia. While Banda lies in the wooded savanna some distance north of the forested heartland of Asante, the agricultural regimes of the two regions had much in common. Both areas relied on some of the same crops, though Banda's drier position meant that oil palms and plantains were not widely grown. Both areas also relied on slash-and-burn and multicropping techniques. And there is considerable evidence for communication and active trading between the two zones. For example, several animal species found only in moist tropical forest are recovered in Banda's archaeological record (Logan and Stahl 2017). For generations, Banda was involved in lucrative trade between the forest and savanna that was brokered by nearby Begho, a well-known entrepôt that peaked between the fifteenth and eighteenth centuries (Posnansky 1987).

Begho's decline may well have been associated with Asante's rise, and particularly the sacking of neighboring polities like Bono Manso in the eighteenth century. In Banda, there seems to be a gap in the archaeological record between circa 1650 and $1750 \mathrm{AD}$, but it is not clear whether this is a real pattern or an artifact of 
gaps in dating methods (Stahl 2001, 161). Populations may have dispersed during a period of instability in the wake of Begho's decline (Stahl 2001, 161), perhaps as a result of a declining resource base (Goucher 1981) or simply a lack of economic opportunities, as Asante wrested control of trade (Posnansky 1987). Whatever the case, oral histories record the arrival in Banda of a new group, the Nafana, from northeastern Côte d'Ivoire sometime after the fall of Begho and before the arrival of the Asante in the eighteenth century. While there seems to have been plenty of space for this new population, the landscape was hardly empty. The Nafanas encountered the ancestors of the modern-day Kuulo (Dumpo) among other ethnic groups such as the Ligby. In ensuing negotiations the Nafana wrested political control over the area, and the Kuulo retained power over the land via the office of earth priest (Stahl 1991).

The Banda polity emerged before 1751, probably by about 1720 (Stahl 2001,150-51). In the first half of the eighteenth century, the Asante took control of most of Banda's eastern and southern neighbors. Asante invaded Banda in 1733 in retaliation for the killing of an Asante trader (Arhin 1987, 53), but it was not until attacks in the dry season of 1773-74 that the Asante established formal hegemony over Banda. Oral histories record the traumatic nature of this war (Ameyaw 1965 in Stahl 2001, 155-58). Upon their acquiescence, Banda's chiefs agreed to provide a yearly tribute in sheep. To help offset the costs of war, many young men from Banda were taken as captives to Kumasi, where they were trained in service to "stools," that is, offices (Wilks 1975, 246). Other captives from Banda were sent to the coast to be consumed in the Atlantic slave trade (Yarak 1979 in Stahl 2001, 155; Stahl 2015). In the section to follow, I consider how food security was impacted by these violent encounters with Asante, as well as the experiences of those who were sold as slaves along the coast. In this section I focus on the archaeological record from Banda itself, which represents those who lived under Asante rule in the late eighteenth and early nineteenth centuries.

By the early decades of the nineteenth century, Banda was counted among Asante's inner provinces, and joined the Asante in wars with neighboring polities such as Gyaman (map 3; Stahl 1991, 260; Stahl 2001, 156-58). Asante influence on Banda's political and economic institutions appears to have been quite pronounced, given the similarities in the structure of Banda's chieftaincy as well as the transformations in regional and long-distance trade and craft production (Stahl 1991, 2001), so we might hypothesize that foodways were also impacted. Stahl $(2007,70-71)$ suggests that incorporation into the Asante empire probably afforded Banda a degree of security and stability. However, this security came at a cost: Banda soldiers were required for Asante's military campaigns, and not only did Asante controlled access to many imported goods, but also, as an inner province, Banda was required to pay taxes (Stahl 2007, 70-71).

The costs of being under Asante control are visible in Banda's shifting political economic base, especially compared to the earlier time periods covered in chapter 2. 
Namely, people were not as invested in producing large quantities and varieties of crafts as they had in previous centuries (Stahl 2001; chapter 2). During the period of Asante dominance, women were particularly important in crafting pottery and making thread, while men were known as weavers (Stahl and Cruz 1998). Instead of focusing on long-distance Niger trade, people invested in trade on an immediate and regional scale (Stahl and Cruz 1998; Stahl et al. 2008). This focus on more localized trade networks might have helped build and cement social and economic relationships with neighboring regions. The end of significant longdistance trade may also have been imposed by the Asante, who strove to reroute lucrative trade networks through Kumasi (Arhin 1970; Wilks 1962).

People also constructed their daily lives somewhat differently than they had in previous centuries. While villages were numerous across the Banda landscape, they were somewhat smaller and less aggregated than in previous centuries (Smith 2008, 548). Some chose to live in new villages, and others returned to population centers of earlier centuries like Ngre Kataa. Our best resolution comes from a new village, Makala (Kataa), which was the first settlement of the Nafana people upon their arrival east of the Banda hills beginning in the 1720s (Stahl 2001, 162). ${ }^{8}$ At about eighteen hectares or thirty-three American football fields (Stahl 2001, 165) in size, Makala Kataa was a large village, but it was still much smaller than Kuulo Kataa (fifty-two football fields). I analyzed plant remains from two houses buried in Mound 5 and Mound 6 in Makala Kataa. Mound 5 was an exceptionally well-preserved outdoor kitchen, and will be discussed in detail below. Mound 6 included several rooms with far fewer plant remains recovered, attesting to the well-swept nature of interior spaces. A smaller subset of samples was analyzed from two outlier villages, B-112 and A-212 Mound 1, to help provide regional coverage (see introduction, map 2). Full results are reported in appendix B.

Unlike in the preceding phases, environmental conditions were optimal during the time people lived at Makala Kataa. Paleoenvironmental records from Lake Bosumtwi suggest that while periodic droughts occurred, average rainfall was significantly higher than in previous centuries, on par with or greater than in the present day (Shanahan et al. 2009; contra Wilks 2004). Farmers increased the amount of sorghum they cultivated to account for elevated rainfall $(28 \%$ ubiquity), although pearl millet was more common (45\% ubiquity), suggesting continued cultural preference for this grain. Although conditions were perfect for maize production, it remained uncommon in the kitchen ( $12 \%$ ubiquity), despite the widespread use of maize cobs as a decorative roulette on pottery. That people continued to opt for indigenous staples instead of maize despite ideal rainfall complicates the McCann/Wilks Big Bang thesis. Very rarely do people make choices based on optimal yield of calories; rather they prefer to eat those foods that taste the best to them and are part of familiar local cuisines. Because of this long period of experimentation, it seems likely that farmers were well aware of maize's ability 
to produce two crops per year, yet the need for extra calories or a stopgap crop was missing, suggesting a relatively comfortable level of food security.

Yet the archaeological record also suggests that a range of circumstances and tastes complicated this scenario. People living at A-212 and Makala Kataa Mound 6 did not care for maize at all, to judge from its absence in those contexts. By the same logic, people who inhabited B-112 appear to have disliked sorghum, since it was absent entirely. B-112 is far to the southeast of Makala Kataa, and may have been occupied by different social groups. Oral traditions record it as a Mo settlement that Nafanas migrated to, and in time the Mo became disgusted and moved away (BRP 2002, 45). While I hesitate to assign these remains any sort of "ethnic" affiliation, Mo or otherwise (see Stahl 1991), varying reliance on staple grains may reflect seasonal or social differences and confirm the hybrid, frontier-like character of the Banda landscape at this time. Food may have even served as a means to come together over shared tastes in this multiethnic landscape. Pearl millet alone appears to have been desired in every village, since the grain occurs at all sites ranging from $20-100 \%$ ubiquity.

Yams (Dioscorea spp.) were probably also a critical part of peoples' diets in Banda, though we lack direct evidence since tubers do not preserve well. However given their mention in Bowdich's account of Asante, we know they were a desired food staple in the broader culinary landscape. Today, Banda lies within Ghana's most productive yam zone, and the desirable rainfall levels during the eighteenth and nineteenth centuries suggest an ideal habitat for yams. We can hypothesize that they comprised a major part of Banda's foodscape, though this awaits empirical verification.

Wild plants increased the variety of nutrients and tastes in what were likely starch-dominated diets. People may have eaten several leafy greens whose seeds were recovered, including Cassia tora, members of the Chenopodiaceae or Amaranthaceae families (cheno-ams), at least two Portulaca species, and Zaleya pentandra. As mentioned in the previous chapter, Cassia tora imparts a slippery texture to soups, suggesting a continued preference for this mouthfeel. People also enjoyed baobab, perhaps as an added leaf to soups, or in the form of a sweet-sour drink that is still made today out of baobab seeds. Wild plants were important for nonfood uses as well, as suggested by a cache of kapok seeds (Ceiba pentandra); kapok provides not only seeds that can be fermented into a flavoring agent for soups known as kombotoo (chapter 5), but also fiber used for bedding and pillows today. Shea butter was probably the main plant oil, providing families with an important source of fat and flavor, but it does not show up often or in great quantities in the archaeological record, perhaps hinting that oil was acquired through trade or produced outside the villages. Today shea butter trees are found in quantity only at the far northern edge of Banda territory, and the wetter conditions of the eighteenth and nineteenth centuries were probably even less ideal for the encouragement of local groves. 
While people continued to eat many of the same plant foods, meat consumption is one area that was drastically different than in preceding centuries. Mean density of animal bones decreased significantly across all classes of animals, from rodents and lizards to cows and sheep. The mean density of bovids and artiodactyls, classes which include domestic sheep and goats as well as cattle, are at their lowest point in Banda's millennium-long occupation (Logan and Stahl 2017, 1388). Herders may have had a more difficult time keeping animals healthy, as wetter conditions would have increased the tsetse fly populations and increased the risk of sleeping sickness. Livestock was also in high demand in Asante's forest core (Arhin 1987, 57; Bowdich [1819] 1873, 272), where it was even more difficult to rear animals. After they were conquered in 1774, Banda's leaders agreed to provide Asante a yearly tribute in sheep (Wilks 1975, 246); by the late nineteenth century, Banda was on a well-known livestock trading route (chapter 4) that may hint at early nineteenth-century antecedents. We know less about how this apparently reduced meat consumption impacted health and cuisine.

That people supplemented their diets with wild animals that could be acquired locally seems clear. Animals like rodents and lizards that are easily acquired through opportunistic encounters are present in the record. Overall, however, people acquired a much less diverse array of animals than in previous centuries. The dangerous animals that would have been encountered at the markets of Kuulo Kataa are virtually absent from Makala Kataa (Logan and Stahl 2017; Stahl 1999b). This pattern may hint at an absence of skilled hunters, which makes sense given the influx of Nafana newcomers who would have had to acclimatize to their new landscape. Some protein tastes were acquired from the Asante heartland (McCaskie 1995, 29), particularly for snails (Stahl 1999b, 54). But compared to the Asantehene's diet, that of the average Banda resident was probably quite modest. In particular, there is less meat from a much narrower range of animals.

Food preparation can tell us a lot about status and local tastes, although at present our available archaeological data speak to this issue only in a limited way. Phytoliths (see chapter 1 and appendix A for description of method) are microscopic silicified plant tissues that are found on the tools people used to prepare food as well as in sediments in areas where people prepared and consumed food. While this type of analysis has not yet realized its potential in the African continent, a small sample of artifacts and sediments were tested from Banda. An earlier study by Deborah Pearsall (see Stahl 1999b, 35-36) found phytoliths that are used to identify maize in South America at Mounds 5 and 6 at Makala Kataa. ${ }^{9}$ Subsequent methodological assessment suggests that these phytolith forms may derive from wild and domesticated African grasses and must be interpreted with caution (Logan 2012). However, using a refined methodology, I analyzed four soil samples and residues from two artifacts (see sampling details in appendix A). Results generally confirm the pattern observed in charred remains: probable presence of 
pearl millet in every context sampled, with many also containing sorghum, and no strong indication of maize (appendix B; Logan 2012).

Two contexts are worth special mention. The first is an area immediately below a grindstone in the MK Mound 6 structure $(2 \mathrm{~W} 24 \mathrm{~N}, \mathrm{Lev} .8)$ which contains a very high proportion of sorghum phytoliths, including several types that may be unique to sorghum. There is also a moderate probability that sorghum is present on a spherical hand grinder recovered from the MK Mound 5 kitchen area (oW ${ }_{2} \mathrm{~S}$ ). These data hint that sorghum was being processed into a ground food product, contrary to Nafana oral histories which insist it was not eaten.

Another way we can assess food preparation is to look at the spatial organization of food activities. An exceptionally well-preserved kitchen was uncovered in Mound 5 at the village of Makala Kataa. The kitchen was probably used between 1774 and the 1820s, after which it was rapidly abandoned, leaving many of the original artifacts and foodstuffs in place (Stahl 2001, 169-71). ${ }^{10}$ While most of the other archaeological contexts I discuss were accumulated in diverse ways and often over long time periods, the Makala Kataa Mound 5 kitchen provides rare insight into food preparation. In what follows, I attempt to transport the reader back in time to this kitchen to better understand the experience of its inhabitants. The following narrative should be paired with figures 2 and 3 , which show the spatial distribution of these activities, as well as quantitative data on plant representation in appendix B.

It is a late afternoon sometime around 1825 , and you are visiting the compound now buried in Mound 5 (Stahl 2001, 169-71). You are drawn to the focal point of the courtyard: the hearth, where the family women are busy preparing dinner. The cook looks up and greets you from one of the two hearths-a roofed one if it is raining (excavation unit $4 \mathrm{~W} 4 \mathrm{~S}$ ), or the three-stone laterite hearth nearby $(2 \mathrm{~W}$ ${ }_{4}$ S) if the sky is clear. She is preparing a sauce of wild greens, selected from nearby pots $(4 \mathrm{~W} 4 \mathrm{~S})$ which may contain the herbaceous Portulaca, a favorite throughout West Africa, or one of the many edible species belonging to the Chenopodiaceae or Amaranthaceae (cheno-am) families. ${ }^{11}$ Fish (perhaps dried) stands ready in a pot $(2 \mathrm{~W} 4 \mathrm{~S})$ nearby to be added to the soup. Carefully hung in the rafters and stacked beneath the pole-and-thatch roof of the wet-season kitchen are piles of harvested sorghum and pearl millet heads and stacks of pots containing ingredients $(4 \mathrm{~W} 4 \mathrm{~S}, 4 \mathrm{~W} 2 \mathrm{~S}) .{ }^{12}$ Just a couple meters away $(2 \mathrm{~W} 4 \mathrm{~S}$, oW $4 \mathrm{~S})$, grains are being liberated from glumes and stalks as part of their transformation into food. ${ }^{13}$ Some of the older daughters are busy processing grains and grinding them on the large grinding stones that ring the fire (oW $4 \mathrm{~S}, 6 \mathrm{~W}$ oS to $2 \mathrm{E} 2 \mathrm{~S}$ ), after which they will be cooked and beaten into a thick porridge.

While some of the women are cooking, other household members are engaged in other activities or are simply relaxing in the compound. A few older men and women are smoking a pipe full of tobacco near the bank of rooms to the northeast (oW oS to $4 \mathrm{E} 2 \mathrm{~S}$ ). The cook too will get her turn: a pot with tobacco sits ready in the wet-season kitchen area $(4 \mathrm{~W} 2 \mathrm{~S})$. Had you arrived somewhat earlier one of the women would have been busy crafting pots, creating just the right paste 


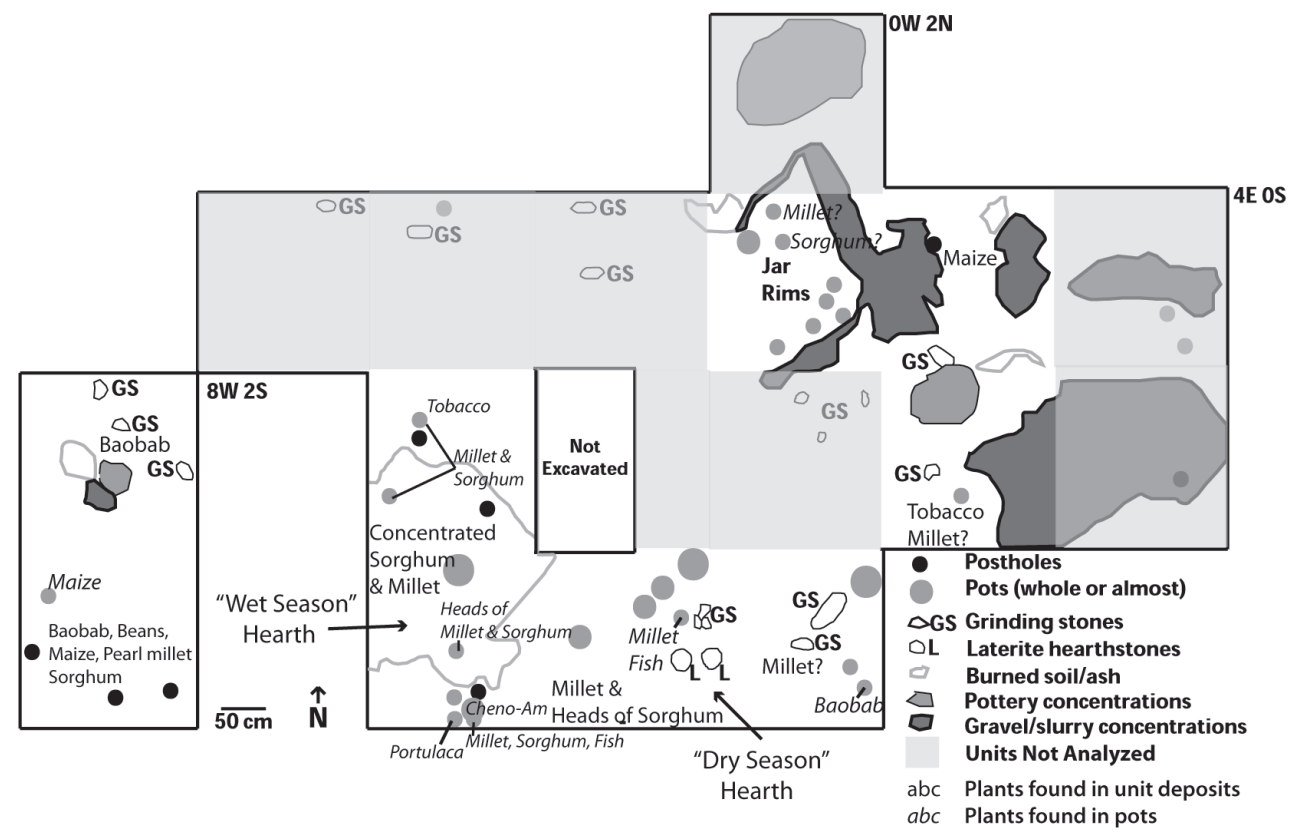

FIGURE 2. Plant remains identified in Early Makala kitchen deposits at Makala Kataa, Mound 5 (base map redrawn from Stahl 2001, 170).

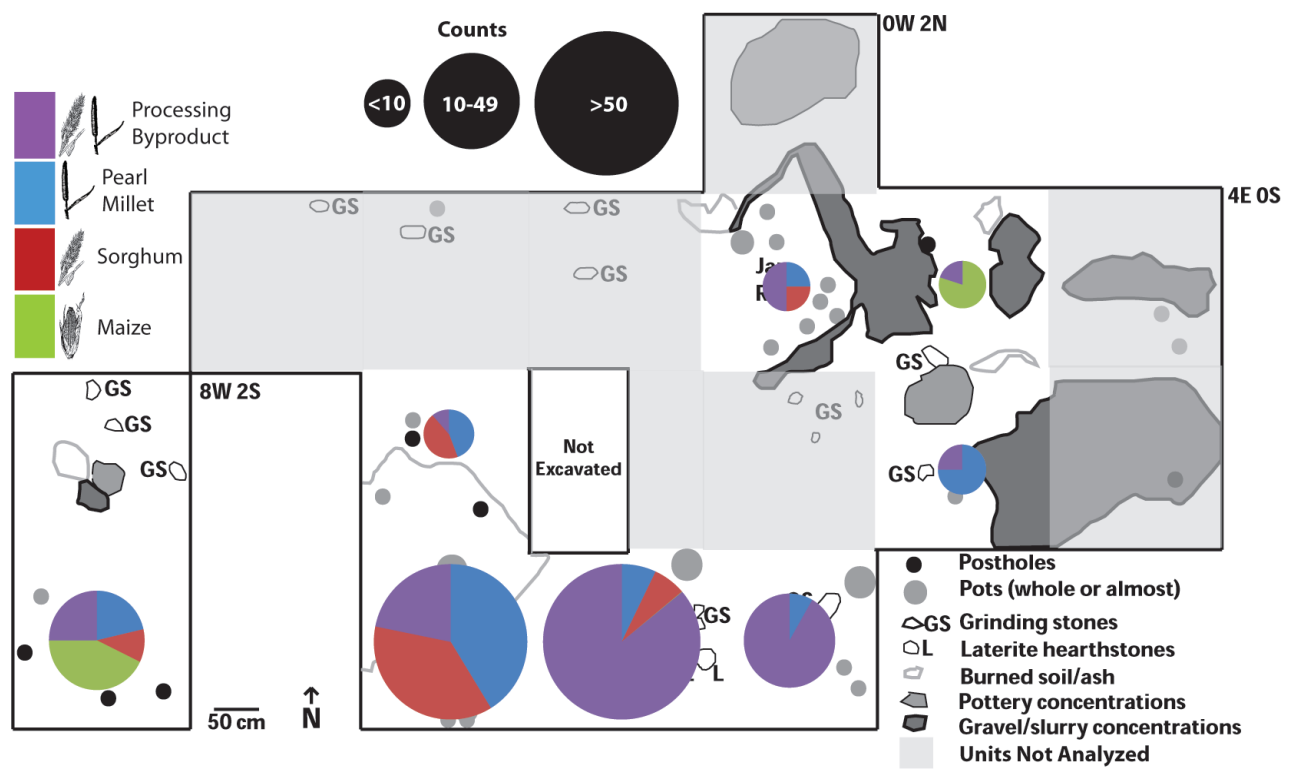

FIGURE 3. Distribution of grain crops and their byproducts in Early Makala kitchen deposits at Makala Kataa, Mound 5. 
mixture on grinding stones ( $8 \mathrm{~W} 2 \mathrm{~S}$ ), or using specially fashioned convex sherds to smooth and thin pot walls and a maize cob to decorate their outside, stowing these tools in a pot $(8 \mathrm{~W} 4 \mathrm{~S})$ after finishing for the day. ${ }^{14}$ Another person nearby is busy processing foodstuffs including baobab, beans, maize, pearl millet, and sorghum, under a pole-and-thatch roof $(8 \mathrm{~W} 4 \mathrm{~S})$. The younger children are already hungry and have managed to hunt down some wild figs (Ficus sp.), spitting out their seeds nearby (oW oS, oW $4 \mathrm{~S},{ }_{4} \mathrm{~W} 4 \mathrm{~S}$ ).

Then the worst happens. Whether because of an accident or because warriors from a neighboring polity suddenly exploded into the village, this tranquil scene is enveloped in fire. It probably started in a cooking hearth, turning to ash most of the ingredients ready to be included in the day's main meal, and charring the carefully harvested piles of sorghum and pearl millet. ${ }^{15}$ In a panic, people dropped everything-pipes, pots, and food-and ran to safety, perhaps to the large cave in the Banda hills that had sheltered their grandparents fifty or so years earlier during the Asante invasion. An enterprising individual grabbed the full storage pots or calabashes that had been nestled in the carefully arranged jar rims that served as pot stands in the storage area (oW oS); the lack of preserved plant remains and other heavily burnt materials suggest this area escaped the fierce blaze that consumed the southern part of the compound. Whatever the cause of this sudden abandonment, household members left behind most of their kitchen equipment and stored grains, and were not able to fetch them later.

\section{TASTING FEAR IN THE MIDST OF VIOLENCE}

As the rapid abandonment of Makala Kataa suggests, the nineteenth century in the Volta basin and throughout large swathes of West Africa was a period of widespread violence and dislocation as groups vied for power and battles erupted (Arhin and Ki-Zerbo 1989; Law 1995). This was related in part to the instability of states like Asante, which faced increasing military and economic pressure from the British beginning in the 1820 s. The abolition of the slave trade in 1807 dealt a major blow to Asante economic power, given the central role of the slave trade in Gold Coast trade at the time (Arhin 1990; Arhin and KiZerbo 1989, 687). As centralized power weakened, so too did Asante's authority over the margins of its empire, leaving its outer territories vulnerable (Arhin and Ki-Zerbo 1989, 663-71; Wilks 1975).

A major source of unrest in areas to the north of the forested region was slave raiding for the internal market, which, despite the British abolition of the slave trade in 1807 , continued into the early twentieth century in some places. This was related to the strong domestic demand for slaves as tribute payments or as laborers, in part to fuel the increasing production of cash crops and gold mines, and as payment for firearms (Arhin 1967b, 76, Arhin 1977, 4; Arhin and KiZerbo 1989, 686; Law 1995). Slaves were captured either through slave catching (i.e., kidnapping) missions or as a byproduct of violent conflict. Decentralized or stateless societies were often the target of slave catching and raiding, but they 
too had developed strategies for dealing with this threat. Though the nineteenth century saw intensification in slaving activities over much of the Volta basin, even in earlier times stronger polities had regularly demanded captives from weaker ones, especially to meet tribute obligations (i.e., Asante demands from Gonja and Dagomba). To avoid capture, people could migrate, develop defensive settlements and strategies, and/or participate in the trade by capturing others (Swanepoel 2005, 274-78). Migratory movements were very common in the nineteenth century, and in many places they underwrite the present-day map of the distribution of ethnic groups (Arhin and Ki-Zerbo 1989, 662; Whatley and Gillezeau 2011).

The pressures brought on by the slave trade and the new ways of living it engendered had multiple impacts on food security. Based on historical sources, Cordell (2003, 40-42) outlined the subsistence strategies of early nineteenth-century central African societies. He points out that monocrop grain fields were particularly vulnerable during raiding: they were not only highly visible as distinct from nearby vegetation, but also required the presence of a farmer at very specific times of year for care and harvest. One adaptation, recounted in numerous historical sources, was to rely more strongly on hunting and gathering, which would leave few signs to be read by hostile marauders. Another possibility was to switch to the cultivation of cassava, which blended in with the surrounding vegetation, required little care, and could be left in the ground for several years and be harvested at any time of year (see also Ferme 2001; Stahl 2008b, 40).

Oral histories of the Banda region recorded at numerous points (Ameyaw 1965; Owusuh 1976; Stahl and Anane 2011; Stahl 2001) emphasize multiple migrations and conflicts and are illustrative of many peoples' experiences during the turbulent nineteenth century. The major period of dislocation seems to have begun after the Banda people joined Asante in war against the neighboring polity of Gyaman (map 3) in 1818-19, eventually fleeing to nearby Bona (Ameyaw 1965). Quarrels and eventually conflict resulted, at which point the people of Banda sought refuge in Gyaman, and with its aid launched retaliation against Bona. Asante entreated the Banda peoples to return to their present-day location, but Gyaman soon attacked, leading Banda peoples to flee the area, this time moving to Mo/Nkoranza (map 3) territory north of the Black Volta River. Disagreements once again erupted with their hosts, and Banda peoples dispersed to various locations, including Bui (chapter 4), a town just south of the Black Volta. Banda again joined the Asante in an 1893 war against the Nkoranza, and the Nkoranza in turn terrorized Banda villages (Arhin 1974, 113; Stahl 2001, 190). Under the new chief Sie Yaw, Banda peoples eventually recongregated at Bui and near modern-day BandaAhenkro, after regaining possession of their land, which had fallen into the hands of Gyaman. In other words, over the course of about one long lifetime, Banda peoples experienced multiple violent conflicts and long-distance moves, which must have had major impacts on their livelihoods and sense of security.

Oral historical sources characterize these times in tragic (perhaps exaggerated) terms (Ameyaw 1965 in Stahl 2001, 155). In the oral histories recounted to me by 
elders in 2009 (chapter 4), based on the experiences of their grandparents and great-grandparents, people recalled that food was in short supply, and people were often too mobile to farm. Most individuals who remembered the stories passed down from their older relatives tell tales of starvation and people left behind (see also Stahl and Anane 2011). There is a sense of haste and motion in the stories, of running and quick decisions, of people and places abandoned in flight. While this highly mobile state surely did not characterize the entirety of the decades-long gap in settlement that we see archaeologically, the moments of flight were traumatic enough to become deeply etched onto cultural memory.

On the move, people hunted wild animals and ate leaves from the bush, along with whatever they were able to grab as they fled their homes or could take from farms encountered in their journeys. Interestingly, maize, millet, sorghum, and yams are not mentioned. This may not be accidental. All of these crops would have required a certain amount of seasonal maintenance, and probably would have withered quickly once their human caretakers departed. Plucking cassava tubers from abandoned farms is mentioned, however, which also makes sense as this is a low-input, hardy crop that can be grown in almost any conditions and at any time of year (see below; cf. Cordell 2003; Ohadike 1981). Wild leaves are an important part of the narrative about the wars; nearly every person who recalled oral histories referring to these traumatic times mentioned wild leaves (chapter 5).

One place on the landscape figures prominently in oral histories of nineteenthcentury turbulence: Banda Rockshelter, which was repeatedly used as a refuge in times of violence. People fled there during Asante's pursuit in the dry season of 1773-74 (Stahl 2001, 157-58), as well as in later conflicts, such as with Gyaman after 1819. ${ }^{16}$ Food shortage is explicitly referred to in both contexts. Famine reportedly forced those hiding in the rockshelter to surrender to Asante (Ameyaw 1965 in Stahl and Cruz 1998, 214), and oral histories stress a return to hunting and gathering during the mid- to late-nineteenth century wars. Though it is impossible to determine the specific conflict to which the material remains in the rockshelter belong, they can speak to activities and strategies adopted during periods of distress.

Unlike village sites, the rockshelter was not excavated extensively, in part due to its smaller areal extent. ${ }^{17}$ Food storage and preparation containers are present. The only other artifacts are a single ceramic bead, a locally manufactured pipe, and porcupine quills (BRP 2002). Botanical remains were likewise scarce in the nine samples available for analysis; even charcoal was present only in limited amounts. Two maize cupules are present, as is one cowpea, and one possible grain of pearl millet. Several different wild seed taxa were discovered, though most could not be identified due to their fragmentary and distorted nature ( $\mathrm{n}=4$ types). Two types were provisionally identified as Apocynaceae and Malvaceae, and appear to be novel to this phase, as neither of these taxa were recovered from samples dating to earlier phases (appendix B).

Though these data are meager, they conjure an image of privation in a dark dank place where use of fire was probably minimal for fear of being discovered. The 
presence of maize, pearl millet, and cowpea is consistent with diets in Early Makala times, but there are several important differences. Sorghum is absent, but maize, rare during Early Makala times, is present. Maize's quick-growing qualities may well have been advantageous during periods of hiding. Though impossible to trace, it seems plausible that cassava was also eaten at this time, especially given its prominence in oral historical accounts and historical documentation in other parts of Ghana, which speak to its widespread use as a famine food (La Fleur 2012). Finally, although it is not possible to narrow down which wild foods were eaten, they clearly differ from foods consumed during the heyday of the Early Makala occupation of Makala Kataa, supporting oral historical accounts of experimentation.

Banda was not alone in experiencing food insecurity during these decades in the middle of the nineteenth century (see chapter 4 ). Widespread violence and dislocation characterized much of West Africa at the time, and violence is among the strongest predictors of severe food insecurity. This was a crisis with both economic and political roots. When the Atlantic slave trade was outlawed by the British in 1807 a prime source of wealth was removed from African polities like Asante, which turned to "legitimate trade" items like gold and oil palm. Yet those commodities also demanded considerable labor inputs, which led to an increase in the internal slave trades (Law 1995). At the same time, the power of Asante was waning as the British struggled to find a foothold on the coast and engaged in repeated conflicts with it. Thus distracted, Asante's control was weakened over marginal areas like Banda (Arhin and Ki-Zerbo 1989).

It is difficult to find information on the nutritional impacts of this widespread violence, but I suspect they were significant in the regions directly affected. Austin, Baten, and van Leeuwen (2012) illustrate a significant decline in the heights of men born in the 1840 from northern Ghana and Burkina Faso, areas that were at the epicenter of mid-nineteenth-century violence as Europeans struggled to gain control of interior West Africa. Height is both genetically and nutritionally determined, with protein consumption being the strongest predictor of overall adult height. Interestingly, there are no significant height declines in cohorts born in the 1800 s-1830s, suggesting that there was a significant interruption in nutrition in the 1840 s but not before that, at least among the populations for whom we have records. Given the association of meat with social status in Asante's core, this sharp drop in protein consumption may well signal sharp increases in inequality as well.

\section{TASTING CAPTIVITY}

Violence splintered social groups and created new ones throughout the period of the trans-Atlantic slave trade and legitimate trade (Whatley and Gillezeau 2011). Victors reaped the spoils of war and left triumphant, while the defeated paid the costs. For some, the costs were especially high. Labor was in high demand internally and from European slave traders along the coast, and the Asante actively acquired human beings to be consumed as commodities in both trades. Banda was 
no exception. A 1774 missive by Pieter Woortman, the Dutch director-general of Elmina, reports better than usual trade in slaves thanks to the Asante defeat of Benda [Banda], which had sent him a "considerable number" of slaves (Yarak 1979, 58; Stahl 2015, 267). These captives may have encountered famine and starvation once they arrived on the coast, as multiple sources record food shortages in that same year (La Fleur 2012, 141). Although we do not know where the newly enslaved from Banda were destined for, nor how many souls were sold, the documentary record reveals the scale of the slave trade, as well as some of the horrors of experiences of captivity at Elmina and in the ensuing Middle Passage. Food, and especially maize, was central to the deprivations suffered during these travails.

Historians, geographers, and economists have long been convinced that there is a relationship between American crops and the slave trade. "As for the influence of these crops before 1850," Crosby ([1972] 2003, 168) proposed, "we might hypothesize that the increased food production enabled the slave trade to go on as long as it did without pumping the black well of Africa dry." Alpern $(1992,13)$ notes that "these crops are said to have improved diets and accelerated population growth, to the point, some would argue, that human losses through the slave trade were more than offset by the enhanced ability to feed people" (see also Curtin 1969). Although this idea has been critiqued by demonstrating the stagnation in population growth in the eighteenth and nineteenth centuries (e.g., Rodney 1972), in modified form it continues to be repeated and tested in recent scholarship in economic history (e.g., Austin, Baten, and Bas van Leeuwen 2012, 1299; Cherniwchan and Moreno-Cruz 2019). Referring to this thesis as the Crosby-Curtin Hypothesis, Cherniwchan and Moreno-Cruz (2019) test the idea that where maize spread populations increased and the trans-Atlantic slave trade peaked. Lacking sufficient data on the precolonial spread of maize, they map out environments suitable to maize cultivation in modern times to substitute for the lack of ancient data. Their country-scale analysis suggests that countries that are best suited to cultivate maize ecologically saw both population increases and greater engagement in the slave trade. They interpret this correlation as indicating that maize resulted in increased populations and thus more people to trade.

Arguments like these are highly problematic for both empirical and conceptual reasons. Estimating the spread of maize based on modern-day ecological data is erroneous since we know environmental conditions were much different at the time of maize's adoption (Shanahan et al. 2009; chapter 2). This kind of estimation also presupposes people automatically adopted this cultigen, removing agency in this decision-making process. As we saw in chapter 2, maize adoption was very slow even in Banda, which is ecologically well suited to its cultivation. And Banda was not alone in slowly adopting maize, as emerging archaeological studies show (Gijanto and Walshaw 2014; Esterhuysen and Hardwick 2017; Widgren et al. 2016). In sum, as with earlier scholarship on this topic, the data used to estimate maize adoption by Cherniwchan and Moreno-Cruz is circumstantial evidence at best; 


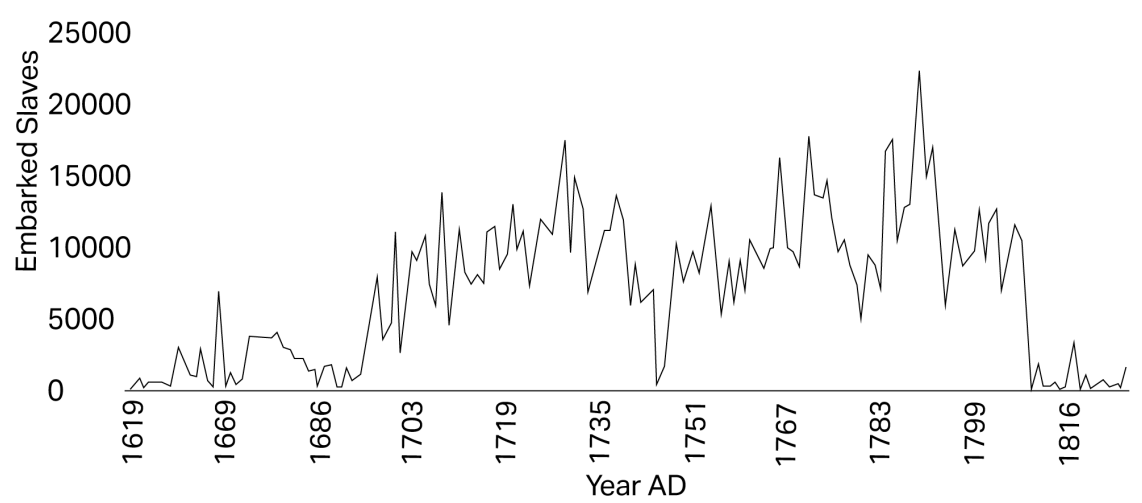

FIGURE 4. Numbers of slaves embarked yearly from the Gold Coast, 1619-1840. Note scale change on X axis between 1619 and 1669. Data from transatlanticslavevoyages.org.

the limited archaeological studies of maize's spread suggest that their model of spread is also empirically incorrect. Archaeological case studies of maize adoption across the diverse ecological and cultural landscape of the continent are sorely needed to understand agency and contingency in the process of food adoption.

If American crops did help make up for population losses suffered to slavery, we would expect there to be a correlation between maize adoption as a staple and the height of slave raiding and exports; indeed, this is precisely what Cherniwchan and Moreno-Cruz set out to test. The time frame encompassed in this chapter corresponds to the height of the Atlantic slave trade in Ghana (figure 4; see TransAtlanticSlaveVoyages.org). From 1700 to 1830, over one million captives were forcefully taken from the slave ports along the Gold Coast. Some of Banda's people were among them. Yet in Banda, an area we know suffered population losses, there is no substantial increase in maize consumption during this time frame, with the exception of a perhaps temporary increase at Banda Rockshelter. Available data from the rest of Asante also do not support an increase in everyday maize consumption among the populace. Additional archaeological data from areas on the margins that were the hardest hit by slave raiding are needed to evaluate this hypothesis. It is only people who inhabited the coast and its hinterlands who appear to have adopted maize as a staple during this time. There, cooks experimented with maize and developed new foods like kenkey, a fermented maize dough that is widely consumed today. What were the circumstances there, and how were they different than in the Asante core and its margins?

Our resolution on coastal foodways is much finer because European engagements there occurred earlier and were more regular, hence the documentary record is more complete. Recent Africanist food scholarship has suggested that maize played a critical role in provisioning captives as well as slave transport ships. Maize had long been provided to captives along the coast, first by the Portuguese, 
who considered the crop unfit for their own consumption (La Fleur 2012, 92). The association of maize and the enslaved seems to have continued into later centuries, as the Gold Coast itself became a major exporter of human cargo especially after 1700 (Lovejoy 2011). Maize provided an economic opportunity for coastal farmers and traders who could easily turn a profit trading the grain to slavers and ship captains (Carney and Rosomoff 2009; Miracle 1965). High demand for foodstuffs elevated crops from significance in local and regional trade to significance in international commerce-the cash crops of the early modern era. In the long run, a shift to the exporting of human captives must have had major impacts on agricultural production, since it depleted the rural labor force of men and women in their primes (Carney and Rosomoff 2009, 46-56). Yet at least along the coast, we see an intensification of agricultural production through maize to take advantage of the demand for grains from European ships. We can only speculate as to whether enslaved labor was used to cultivate maize along the coast. While providing economic security for local farmers, maize was also purportedly the staple of slave transport ships (Miracle 1965), and thus "a symbol of the dehumanizing condition of chattel slaves, who were no longer able to exercise dietary preferences or choose the type or amount of food they consumed" (Carney and Rosomoff 2009, 55). Maize, in this formulation, falls from being the "grace" or savior of Africa (McCann 2005) to being a reminder of one of the darkest periods of its history. "This Columbian Exchange crop flourished because its cultivation and preparation made the cereal ideally suited to the trade in human beings" (Carney and Rosomoff 2009, 55), not because the forest lacked in carbohydrates.

\section{FOOD AND INEQUALITY IN ASANTE AND ITS MARGINS}

For the last half century, discussion of Asante foodways has focused on food supply and the potential role that American crops played in increasing food availability. In this chapter, I have tried to debunk some of the assumptions of the Big Bang hypothesis, and the related idea that American crops made up for population losses suffered during the slave trade. Similar starting assumptions are at the root of both explanations: that the context into which these new crops were received was lacking in adequate food supplies and local food traditions, and that Africans did not possess the knowledge to develop solutions through exploiting local environments. In this chapter I have offered a different and more complex narrative by highlighting some of the diverse African agencies and situations that characterized the eighteenth- and nineteenth-century foodscape. This approach brings to life the contexts into which American crops were received, rejected, and adopted, a diversity that troubles the foundations of simplistic Malthusian explanations for their adoption. 
Foodscapes of the eighteenth to early nineteenth centuries occupied the full spectrum of choice and possibility that map on to increasingly unequal power relations. While I have only touched on the role that food played in status displays of the Asantehene and his retinue, the wide range and quantity of meat and plant foods consumed by elites were impressive. They resulted from a highly organized, productive agricultural system built on yams, plantains, and multiple kinds of grain, as well as an extensive empire that extracted food and many other products from subject nations like Banda. American crops seem to have been absent from these sumptuous displays. This absence is notable since other exotic foods were clearly desirable, hinting that American crops were not part of distinction-making practices. The continued preference for local foods is in stark contrast to the desire for other foreign consumables, chief among them alcohol. Local alternatives like palm wine were replaced with foreign rum and schnapps whenever possible, and these beverages continue to play important roles in marking power among chiefs even today (Akyeampong 1996; for cloth and tobacco, see Stahl 2002).

Yet many of the Asantehene's subjects lacked access to this full range of foods and may have preferred other kinds of foods that were valued locally. The people who lived in Banda subsisted primarily on pearl millet and sorghum (and likely yams as well), which had been the staples of their ancestors. Maize remained a minor component of their diets, even if it was more widely available than it had been in the past. People's meat consumption changed from preceding time periods; not only do we find a smaller quantity of meat, but people focused on more easily acquired animals rather than the novel, diverse menu that their ancestors had enjoyed. While there are many possible explanations for this change, it is clear that the Asante Empire had a major impact on local political economies. Banda's long-distance trade networks seem to have contracted and been redirected towards Asante. Banda's residents were also obliged to pay tribute to Kumasi in the form of livestock.

While Asante control impacted foodscapes and daily life for subjects on the margins, its most devastating effects were felt during periods of violence and its aftermath. We know of at least two periods of violence in Banda, associated with Asante's takeover in 1773-74 and with wars beginning in the 1820 s and continuing periodically through the mid-nineteenth century. Oral histories record people fleeing to take shelter in the Banda hills and subsisting off what little produce they could acquire as well as leaves and animals from the bush. Maize and cassava were important in conditions like these in Banda and elsewhere along the Gold Coast, when culinary preference was secondary to simply meeting dietary needs. For the areas hardest hit by violence, the disruption in normal food supplies seems to have impacted lifelong growth and development, as observed in a drastic decline in height in men from northern Ghana and Burkina Faso in the 1840 s.

This brief survey of foodscapes of the eighteenth and nineteenth centuries reveals that American crops such as maize were not adopted because African 
agriculture was incapable of supporting Africans. Where people had access to preferred foods, American crops were usually not what was chosen. Where it made economic sense, such as along the coast, farmers and traders made a strategic choice to grow, eat, and trade maize. When choices were constrained during bouts of violence, people made the strategic choice to cultivate and consume maize and cassava, the crops that grew the quickest or easiest. And when choice was denied altogether, people ate what was provided them or made the agonizing decision not to eat at all. In the next chapter, I show how this diverse and unequal political and culinary landscape contributed to the making of chronic food insecurity in the generations to come. 